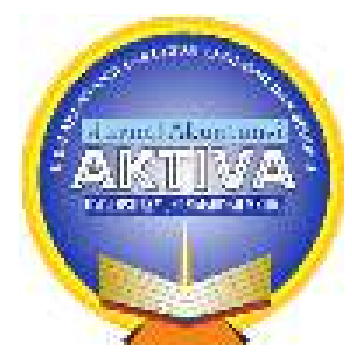

Jurnal Akuntansi AKTIVA, Vol 1, No 1, April 2020

\title{
FAKTOR-FAKTOR YANG MEMPENGARUHI MINAT MAHASISWA AKUNTANSI TERHADAP PEMILIHAN KARIR SEBAGAI CERTIFIED PUBLIC ACCOUNTANTS OF INDONESIA
}

\author{
${ }^{1 *}$ Hendra Rahmat Pratama, ${ }^{2}$ Elmira Febri Darmayanti \\ ${ }^{1,2}$ Fakultas Ekonomi dan Bisnis Universitas Muhammadiyah Metro, Lampung, Indonesia \\ ²email: efdarmayanti@gmail.com
}

\begin{abstract}
This study is to find empirical evidence of the factors that influence the interest of accounting students towards career selection as a certified public accountants of Indonesia. The technique in taking samples in this study was random purposive propotional so that the samples obtained were 85 students. This research is a study that uses a quantitative approach. Data were analyzed using the help of the SPSS 20 program with the type of analysis namely multiple linear regression. The results obtained from this study indicate that based on partial testing career prospects, labor market, social values, have a positive influence on career selection as a public accountant, but professional recognition has a negative influence on career selection as a public accountant. As well as the simultaneous testing shows that career prospects, professional recognition, labor market considerations and social values together influence the interest of accounting students at Muhammadiyah Metro University in choosing careers as public accountants.
\end{abstract}

Keywords: Career Prospects, Professional Recognition, Labor Market Considerations, Social Values and Interest in Accounting, Career Selection as a Public Accountant.

\begin{abstract}
ABSTRAK
Penelitian ini untuk menemukan bukti empris faktor-faktor yang mempengaruhi minat mahasiswa akuntansi terhadap pemilihan karier sebagai Certified Public Accountants of Indonesia. Teknik dalam pegambilan sampel dalam penelitian ini adalah purposive propotional random samping sehingga sampel yang diperoleh sebanyak 85 mahasiswa. Penelitian ini merupakan penelitian yang menggunakan pendekatan kuantitatif. Data dianalisis menggunakan bantuan program SPSS 20 dengan jenis analisis yaitu regresi linier berganda. Hasil yang diperoleh dari penelitian ini menunjukkan bahwa berdasarkan pengujian secara parsial prospek karier, pemilihan karir, pertimbangan pasar kerja mempunyai pengaruh yang positif terhadap pemilihan karir sebagai akuntan publik, sedangkan pengakuan profesional mempunyai pengaruh yang negatif terhadap pemilihan karir sebagai akuntan publik. Hasil pengujian secara simultan menunjukkan bahwa prospek karier, pengakuan profesional, pertimbangan pasar kerja dan nilai-nilai sosial bersama- sama berpengaruh terhadap minat mahasiswa akuntansi di Universitas Muhammadiyah Metro dalam pemilihan karier sebagai akuntan publik.
\end{abstract}

Kata Kunci: Prospek Karir, Pengakuan Profesional, Pertimbangan Pasar Kerja, Nilai Sosial, dan Minat Pemilihan Karir sebagai Akuntan Publik. 


\section{PENDAHULUAN}

Profesi Akuntan Indonesia akan selalu menghadapi berbagai tantangan baru setiap tahunnya, baik tantangan yang datang dari dalam profesi maupun dari luar profesi. Tantangan dari luar profesi datang dari berbagai pihak, mencakup meningkatnya tuntutan Good Corporate Governance (GCG) dari pihak pemakai jasa akuntan, regulasi yang lebih ketat oleh pemerintah, serta tantangan menjaga kepercayaan pemerintah ditengah-tengah masih sedikitnya jumlah akuntan publik di Indonesia (Patama, 2018). Peningkatan jumlah perusahaan setiap tahunnya yang didukung dengan banyaknya perusahaan yang sudah menerapkan GCG, akan menuntut peran akuntan publik untuk menjamin prinsip, transparansi, akuntabilitas, pertanggung jawaban, independensi, dan fairness. Untuk itu, peningkatan jumlah perusahaan yang mempunyai peminat yang besar terhadap profesi akuntan publik harus di imbangi dengan peningkatan jumlah lulusan-lulusan akuntansi yang ingin atau berkarier sebagai akuntan publik. Akuntan Publik itu sendiri merupakan seorang praktisi dengan gelar profesional yang diberikan kepada seorang akuntan yang telah mendapatkan izin dari Menteri Keuangan Republik Indonesia untuk memberikan jasa-jasa tertentu.

Hasil penelitian yang dilakukan oleh Senoadi (2015), menunjukkan bahwa faktor yang mendorong mahasiswa untuk memilih karir sebagai Akuntan Publik, karena ada kepuasan tersendiri ketika memperoleh pengakuan profesional atau pengakuan prestasi kerjanya dalam karir akuntan publik, mengingat dibutuhkan keahlian tertentu, waktu yang tidak sebentar dan jenjang karir yang panjang. Adanya faktor yang mendorong mahasiswa akuntansi untuk cenderung memilih akuntan publik sebagai pemilihan karirnya karena dengan informasi semakin banyak perusahaan-perusahaan yang berdiri baik dalam perseorangan maupun perusahaan berbentuk badan hukum jasa seorang akuntan publik akan semakin banyak dicari dan hal ini menyebabkan semakin banyak peluang kerja yang ditawarkan. Berbeda dengan hasil penelitian dari Merdekawati dan Sulistiyawati (2011) yang meneliti tentang faktor-faktor yang mempengaruhi pemilihan karier sebagai akuntan publik dan non akuntan publik dengan menggunakan variabel penghargaan finansial, pelatihan profesional, pengakuan profesional, nilai-nilai sosial, lingkungan kerja, pertimbangan pasar kerja, dan personalitas. Hasil penelitiannya menunjukkan bahwa penghargaan finansial, pertimbangan pasar kerja dan personalitas tidak berpengaruh secara signifikan terhadap pemilihan karier sebagai akuntan publik dan non akuntan publik.

Ketentuan mengenai akuntan publik di Indonesia diatur dalam Undang-Undang Republik Indonesia Nomor. 5 Tahun 2011 tentang Akuntan Publik dan Menteri Keuangan Nomor 17/PMK.01.2008 tentang Jasa Akuntan Publik. Setiap akuntan wajib menjadi anggota Institusi Akuntan Publik Indonesia (IAPI) yang di akui oleh pemerintah. Dalam masyarakat umum, profesi akuntan publik merupakan profesi yang prestigious. Profesi ini dicapai secara tidak mudah, namun harus melalui pelatihan dan pendidikan. (Bere Laka, 2019). Faktor-faktor yang mempengaruhi pemilihan karir mahasiswa dan jenis karir yang akan mereka jalani merupakan hal menarik untuk diteliti karena dengan diketahuinya pilihan karir yang diminati mahasiswa, maka dapat diketahui mengapa seseorang memilih karir tersebut. Minat dan rencana karir yang jelas akan sangat berguna dalam penyusunan program agar materi kuliah dapat disampaikan secara efektif.

\section{DESKRIPSI TEORI}

\section{The Theory of Planned Behavior (TPB)}

Teori perilaku terencana menekankan pada niat perilaku sebagai akibat atau hasil kombinasi beberapa kepercayaan Ajzen dan Madden (1986). Niat merupakan konsepsi dari terencana dalam mencapai tujuan berperilaku, teori ini memperhitungkan bahwa semua perilaku tidaklah dibawah kendali dan sepenuhnya diluar kendali. Sebenarnya perilaku- perilaku tersebut berada pada suatu titik dalam suatu kontinum dari semulanya di bawah kendali menjadi tidak terkendali. Dalam keadaan ekstrim, mungkin sama sekali tidak terdapat kemungkinan untuk mengendalikan suatu perilaku karena tidak adanya kesempatan dan karena tidak adanya sumber daya atau keterampilan. 


\section{Profesi Akuntan}

Praktik akuntansi di Indonesia sejak zaman VOC (1642). Akuntan-akuntan Belanda mendominasi akuntansi di perusahaan-perusahaan yang juga dimonopoli penjajah, hingga abad 19. Perkembangan itu semakin pesat setelah presiden meresmikan kegiatan pasar modal 10 Agustus 1977 yang membuat peranan akuntansi dan laporan keuangan mnjadi penting. Januari 1977 Menteri Keuangan (Menkeu) mengeluarkan surat keputusan No. 43/1997 tentang jasa akuntan menggantikan keputusan Menteri Keuangan (Kepmenkeu) 763/1986. Selain mewajibkan akuntan publik memiliki sertifikat akuntan publik, akuntan publik asing juga diperbolehkan praktek di Indonesia sepanjang memenuhi persyaratan.

\section{Kerangka Pemikiran}

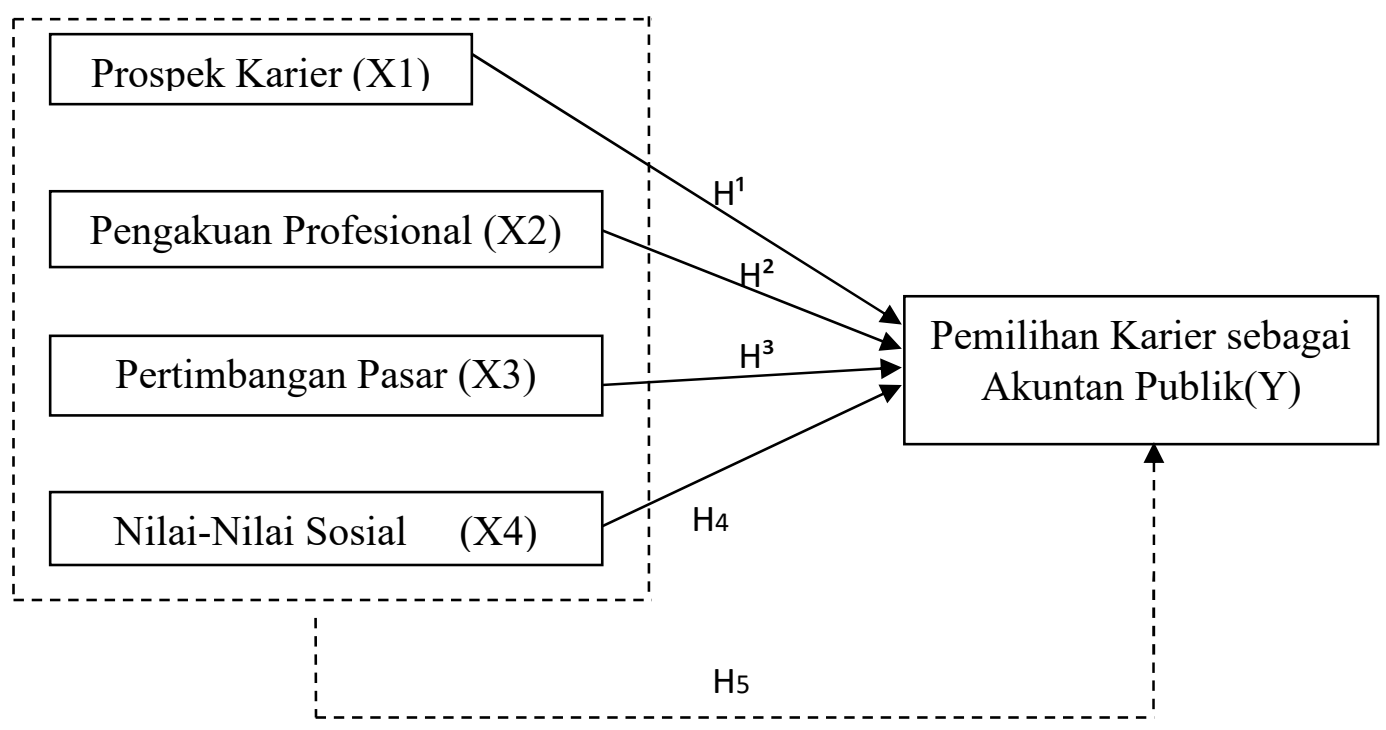

Gambar 1. Kerangka Pemikiran

\section{Pengaruh Prospek Karier terhadap Minat Pemilihan Karier}

Menurut Senjhari (2016). Prospek karier sangat diperlukan karena perusahaan memberikan peluang bagi kemajuan dan promosi bagi karyawannya. Prospek karier diperoleh dari belajar, pengamatan, dan pengalaman sedang sumber pengetahuan dapat berasal dari buku-buku, televisi, radio, pameran-pameran, majalah, surat kabar, maupun pengamatan langsung terhadap pemilihan karier. Pandangan karier seseorang yang semakin banyak tentunya akan menyebabkan seseorang berhasil dan akan memberikan efek yang menyenangkan dan akhirnya akan mempertinggi minat pemilihan karier. Oleh sebab itu maka Prospek Karier ini diduga memiliki pengaruh positif terhadap minat pemilihan Karier mahasiswa Akuntansi.

\section{H1: Prospek Karier Berpengaruh Terhadap Minat Menjadi Akuntan Publik.}

\section{Pengaruh Pengakuan Profesional terhadap Minat Pemilihan Karier}

Menurut Lara Absara Apriliyan (2011). Pengakuan profesional merupakan suatu penghargaan yang berwujud non-finansial yang berhubungan dengan pengakuan terhadap prestasi. Dengan diakuinya prestasi kerja akan dapat meningkatkan kualitas pekerjaan yang dihasilkan dan dapat meningkatkan motivasi dalam pencapaian karir yang lebih baik. Semakin 
banyak pengetahuan seseorang tentang pengakuan profesional kewirausahaan seseorang, tentunya akan menyebabkan seseorang berhasil dan akan memberikan efek yang menyenangkan dan akhirnya akan mempertinggi minat seseorang terhadap pemilihan karier. Oleh sebab itu maka pengakuan profesional ini diduga memiliki pengaruh positif terhadap minat pemilihan Karier mahasiswa Akuntansi.

H2 : Pengakuan Profesional Berpengaruh Terhadap Minat Menjadi Akuntan Publik.

\section{Pengaruh Pertimbangan Pasar Kerja terhadap Minat Pemilihan Karier}

Menurut Widyanti (2018). Pertimbangan Pasar Kerja meliputi keamanan kerja atau kemudahan mengakses lowongan kerja. Pertimbangan pasar kerja selalu dipertimbangkan mahasiswa dalam pemilihan profesi, karena terpuruknya keadaan perekonomian dan sulitnya mencari kerja, mengakibatkan mahasiswa memperhatikan pasar kerja.Pada kondisi seperti itu tentunya dapat dikatakan bahwa pertimbangan pasar kerja sangatlah berperan untuk mempengaruhi minat mahasiswa Akuntansi, sehingga diduga terdapat pengaruh positif terhadap minat pemilihan Karier Mahasiswa Akuntansi.

H3 : Pertimbangan Pasar Kerja Berpengaruh Terhadap Minat Menjadi Akuntan Publik.

\section{Pengaruh Nilai-Nilai Sosial terhadap Minat Pemilihan Karier}

Menurut Suyono (2014). Nilai- nilai sosial berkaitan dengan pandangan masyarakat terhadap nilai-nilai sosial dari suatu karir yang dipilih. Pekerjaan akuntan publik membutuhkan lingkungan dan situasi sekitar yang baik. Nilai-nilai sosial mendorong pekerjaan akuntan publik lebih dihargai dan mendapat tempat distrata sosial masyarakat. Kepedulian dan perhatian pada sekitar oleh seseorang akuntan akan meningkatkan nilai instrinsik dan nilai jual akuntan. Akuntan publik menyediakan jasanya kepada masyarakat sehingga memerlukan kepercayaan dari masyarakat yang dilayaninya Akuntan publik menyediakan jasanya kepada masyarakat sehingga memerlukan kepercayaan dari masyarakat yang dilayaninya. Pada kondisi seperti itu tentunya akan bisa dikatakan bahwa Nilai-Nilai sosial sangatlah berperan untuk mempengaruhi minat mahasiswa Akuntansi, sehingga diduga terdapat pengaruh positif terhadap minat pemilihan Karier Mahasiswa Akuntansi

H4 : Nilai-Nilai Sosial Berpengaruh Terhadap Minat Menjadi Akuntan Publik.

Dari penjelasan per variabel di atas dapat di simpulkan bahwa pengaruh Prospek Karier, Pengakuan Profesional, Pertimbangan Pasar Kerja dan Nilai-Nilai Sosial saling relevan terhadap Minat Pemilihan Karier.

\section{H5 : Prospek Karier, Pengakuan Profesional, Pertimbangan Pasar Kerja dan Nilai- Nilai Sosial secara bersama-sama Berpengaruh terhadap Minat Menjadi Akuntan Publik.}

\section{METODOLOGI PENELITIAN \\ Jenis dan Objek Penelitian}

Penelitian ini termasuk dalam jenis penelitian deskriptif dengan pendekatan kuantitatif. Pengumpulan data dan informasi dilakukan dengan menyebarkan kuesioner kepada responden yaitu mahasiswa Akuntansi semester VIII FEB Universitas Muhammadiyah Metro. Lokasi penelitian adalah Universitas Muhammadiyah Metro yang beralamat di Jl. Ki Hajar Dewantara No. 116, Kota Metro, Lampung. 


\section{Operasional Variabel}

a. Variabel Dependen (Y): Pemilihan Karier sebagai Akuntan Publik

Variabel dependen yaitu pemilihan karir menjadi akuntan publik. Pemilihan karir menjadi akuntan publik diukur dengan indikator Akuntan Publik dapat menjadi konsultan bisnis yang terpercaya, dapat memperluas wawasan dan kemampuan akuntansi, dapat menjanjikan lebih profesional dalam bidang akuntansi, dan memperoleh penghargaan yang tinggi dimasyarakat

b. Variabel Independen (X1) : Prospek Karier

Merupakan suatu peluang bagi seorang karyawan/pegawai untuk mendapatkan promosi dan jenjang karier yang lebih baik di masa yang akan datang. Prospek karir menggunakan kuesioner yang berkaitan dengan pernyataan mengenai peluang karir (atraktif, jangka panjang), dan tingkat persaingan tinggi.

c. Variabel Independen (X2) : Pengakuan Profesional

Merupakan suatu penghargaan yang berwujud non-finansial yang berhubungan dengan pengakuan terhadap prestasi. Pengakuan profesional diuji dengan menggunakan kuesioner berkaitan dengan pernyataan mengenai kesempatan untuk berkembang, pengakuan prestasi, memerlukan banyak cara untuk naik pangkat, dan memerlukan keahlian tertentu untuk mencapai kesuksesan.

d. Variabel Independen (X3) : Pertimbangan Pasar Kerja

Merupakan sesuatu yang harus dipertimbangkan oleh mahasiswa dalam pemilihan karir, karena terpuruknya keadaan perekonomian dan sulitnya mencari pekerjaan, mengakibatkan mahasiswa harus memperhatikan pasar kerja yang sesuai dengan yang dibutuhkan. Pertimbangan pasar kerja diuji menggunakan kuesioner dengan pernyataan mengenai pertimbangan dimasa yang akan datang, pertimbangan resiko, pertimbangan jam kerja dan pertimbangan sebelum mulai bekerja.

\section{e. Variabel Independen (X4) : Nilai-Nilai Sosial}

Merupakan hal-hal yang berkaitan dengan pandangan masyarakat terhadap nilai-nilai sosial dari suatu karir yang dipilih. Nilai-nilai sosial diuji dengan pernyataan keuesioner mengenai kesempatan untuk melakukan pelayanan sosial, kesempatan untuk berinteraksi dengan orang lain, gengsi pekerjaan di mata orang lain, dan memberi kesempatan untuk bekerja dengan ahli di bidang lain.

\section{Populasi dan Sample}

Populasi dalam penelitian ini adalah mahasiswa Akuntansi FEB Universitas Muhammadiyah Metro yang berdasarkan data yang diperoleh dari Bagian Administrasi dan Keuangan berjumlah 417 mahasiswa. Sedangkan teknik dalam pegambilan sampel dalam penelitian ini menggunakan purposive propotional random samping dengan menggunakan kriteria bahwa responden tercatat sebagai mahasiswa aktif dan merupakan mahasiswa tingkat semester terakhir atau yang sedang menyelesaikan tugas akhir/skripsi di Fakultas Ekonomi Bisnis Universitas Muhammadiyah Metro.

\section{Teknik Pengumpulan Data}

Metode pengumpulan data yang digunakan dalam penelitian ini adalah angket (kuesioner) dan dokumentasi.

\section{Uji Persyaratan Instrumen}

\section{Uji Validitas}

Suatu instrumen penelitian dikatakan valid apabila memenuhi kriteria bila harga korelasi di diatas/lebih besar dari 0,30. Sugiyono (2016) Pengujian validitas instrumen/kuesioner dalam penelitian ini menggunakan software statistik berupa SPSS (Statistical Product and Service Solutions). Ghozali (2018) menyatakan bahwa "uji validitas digunakan untuk mengukur sah atau valid tidaknya suatu keusioner “. 


\section{Uji Reliabilitas}

Uji reliablitias adalah pengujian untuk mengukur suatu kuesioner yang merupakan indikator

dari variabel atau konstruk. Suatu kuesioner dikatakan reliabel atau handal jika jawaban seseorang terhadap pertanyaan adalah konsisten atau stabil dari waktu ke waktu. Uji reliabilitas dilakukan dengan koefesien Alpha Cronbach. Keandalan item pertanyaan dianggap cukup jika nilai koefesien Alpha Cronbach ha lebih dari 0,60.

\section{Uji Persyaratan Analisis}

\section{Uji Normalitas}

Uji Normalitas berguna untuk menentukan data yang telah dikumpulkan berdistribusi normal atau diambil dari populasi normal. Berdasarkan pengalaman empiris beberapa pakar statistik, data yang banyaknya lebih dari 30 angka (n>30), maka sudah dapat diasumsikan berdistribusi normal.

\section{Uji Linieritas}

Uji linearitas bertujuan untuk mengetahui apakah dua variabel mempunyai hubungan yang linear atau tidak secara signifikan. Pengujian ini melihat bagaimana variabel (X) mempengaruhi variabel (Y) baik berpengaruh berbanding lurus maupun berbanding terbalik.

\section{Uji Hipotesis}

Hipotesis merupakan kesimpulan teoritis atau sementara dalam penelitian. Hipotesis merupakan hasil akhir dari proses berpikir deduktif (logika deduktif). Metode yang digunakan untuk menguji hipotesis pertama sampai lima diuji dengan menentukan tingkat signifikansi dengan Uji parsial (uji t) dan Uji simultan (Uji F) sebagai berikut :

\section{Uji t}

Uji t pada dasarnya menunjukaan seberapa jauh pengaruh variabel independen secara individual menerangkan variasi variabel dependen, uji t digunakan untuk menguji secara parsial masing-masing variabel, untuk mengetahui apakah variabel independen secara individual mempunyai pengaruh terhadap variabel dependen.

\section{Uji F}

Uji simultan atau disebut juga uji $\mathrm{F}$ bertujuan untuk mengetahui apakah variabel bebas (X) secara bersama-sama atau secara serempak (simultan) berpengaruh terhadap variabel terikat (Y).Dasar pengambilan keputusan untuk uji F (simultan) dalam analisis r.

\section{HASIL DAN PEMBAHASAN}

\section{Hasil Penelitian}

Sampel dalam penelitian ini adalah mahasiswa semester akhir yang berjumlah 85 responden yang terdiri 26 responden laki-laki dan 56 perempuan. Dalam penelitian ini semua responden yang berjumlah 85 mahasiswa mengisi kuisioner yang diberikan peneliti.

\section{Penentuan Pengujian Persyaratan Instrumen}

1. Uji Validitas Variabel Prospek Karier (X1)

Adapun nilai r-tabel pada taraf signifikansi $\alpha$ 5\% $(0,05)$ adalah sebesar 0,2133 dan hasil dari pengujian validitas variabel (X1) adalah sebagai berikut:

Tabel 1. Hasil Uji Validitas Variabel X1

\begin{tabular}{|c|c|c|c|}
\hline No. Item & R-hitung & R-tabel & Interpretasi \\
\hline 1 & 0,306 & 0,2133 & Valid \\
\hline 2 & 0,358 & 0,2133 & Valid \\
\hline 3 & 0,416 & 0,2133 & Valid \\
\hline 4 & 0,514 & 0,2133 & Valid \\
\hline 5 & 0,458 & 0,2133 & Valid \\
\hline 6 & 0,006 & 0,2133 & Tidak Valid \\
\hline
\end{tabular}




\begin{tabular}{|c|c|c|c|}
\hline 7 & 0,272 & 0,2133 & Valid \\
\hline 8 & 0,384 & 0,2133 & Valid \\
\hline 9 & 0,590 & 0,2133 & Valid \\
\hline 10 & 0,449 & 0,2133 & Valid \\
\hline
\end{tabular}

Sumber: Hasil Pengolahan Data dengan SPSS Versi 20

Berdasarkan Tabel. 1 dapat diketahui bahwa pada seluruh item pertanyaan yang digunakan pada kuesioner prospek karier diperoleh hasil nilai r-hitung yang didapatkan lebih besar dari r-tabel. Dengan demikian dapat dinyatakan bahwa item soal 1,2,3,4,5,7,8,9 dan 10 pada uji validitas variabel prospek karier (X1) layak (valid) dijadikan alat ukur dalam penelitian.

\section{Uji Validitas Variabel Pengakuan Profesional (X2)}

Adapun nilai r-tabel pada taraf signifikansi $\alpha$ 5\% $(0,05)$ adalah sebesar 0,2133 dan hasil dari pengujian validitas variabel (X2) adalah sebagai berikut:

Tabel 2. Hasil Uji Validitas Variabel X2

\begin{tabular}{|c|c|c|c|}
\hline No. Item & R-hitung & R-tabel & Interpretasi \\
\hline 1 & 0,430 & 0,2133 & Valid \\
\hline 2 & 0,386 & 0,2133 & Valid \\
\hline 3 & 0,549 & 0,2133 & Valid \\
\hline 4 & 0,594 & 0,2133 & Valid \\
\hline 5 & 0,516 & 0,2133 & Valid \\
\hline 6 & 0,654 & 0,2133 & Valid \\
\hline \hline 7 & 0,536 & 0,2133 & Valid \\
\hline 8 & 0,469 & 0,2133 & Valid \\
\hline 9 & 0,515 & 0,2133 & Valid \\
\hline 10 & 0,396 & 0,2133 & Valid \\
\hline
\end{tabular}

Sumber: Hasil Pengolahan Data dengan SPSS Versi 20

Berdasarkan Tabel. 2 dapat diketahui bahwa pada seluruh item pertanyaan yang digunakan pada kuesioner pengakuan profesional diperoleh hasil bahwa didapatkan nilai rhitung yang lebih besar dari r-tabel. Dengan demikian dapat dinyatakan bahwa item soal 1,2,3,4,5,6,7,8,9 dan 10 pada uji validitas variabel pengakuan profesional (X2) layak (valid) dijadikan alat ukur dalam penelitian.

\section{Uji Validitas Variabel Pertimbangan Pasar (X3)}

Adapun nilai r-tabel pada taraf signifikansi $\alpha$ 5\% $(0,05)$ adalah sebesar 0,2133 dan hasil dari pengujian validitas variabel (X3) adalah sebagai berikut:

Tabel 3. Hasil Uji Validitas Variabel X3

\begin{tabular}{|c|c|c|c|}
\hline No. Item & R-hitung & R-tabel & Interpretasi \\
\hline 1 & 0,378 & 0,2133 & Valid \\
\hline 2 & 0,039 & 0,2133 & Tidak Valid \\
\hline 3 & 0,346 & 0,2133 & Valid \\
\hline 4 & 0,312 & 0,2133 & Valid \\
\hline 5 & 0,207 & 0,2133 & Tidak Valid \\
\hline 6 & 0,498 & 0,2133 & Valid \\
\hline 7 & 0,619 & 0,2133 & Valid \\
\hline 8 & 0,413 & 0,2133 & Valid \\
\hline 9 & 0,337 & 0,2133 & Valid \\
\hline 10 & 0,403 & 0,2133 & Valid \\
\hline
\end{tabular}


Sumber: Hasil Pengolahan Data dengan SPSS Versi 20

Berdasarkan Tabel. 3 dapat diketahui bahwa pada seluruh item pertanyaan yang digunakan pada kuesioner pertimbangan pasar diperoleh hasil bahwa nilai r-hitung yang didapatkan lebih besar dari rtabel. Dengan demikian dapat dinyatakan bahwa item soal 1,3,4,6,7,8,9 dan 10 pada uji validitas variabel pertimbangan pasar (X3) layak (valid) dijadikan alat ukur dalam penelitian.

\section{Uji Validitas Variabel Nilai-Nilai Sosial (X4)}

Adapun nilai r-tabel pada taraf signifikansi $\alpha$ 5\% $(0,05)$ adalah sebesar 0,2133 dan hasil dari pengujian validitas variabel (X4) adalah sebagai berikut:

Tabel 4. Hasil Uji Validitas Variabel X4

\begin{tabular}{|c|c|c|c|}
\hline No. Item & R-hitung & R-tabel & Interpretasi \\
\hline 1 & 0,629 & 0,2133 & Valid \\
\hline 2 & 0,379 & 0,2133 & Valid \\
\hline 3 & 0,555 & 0,2133 & Valid \\
\hline 4 & 0,636 & 0,2133 & Valid \\
\hline 5 & 0,326 & 0,2133 & Valid \\
\hline 6 & 0,296 & 0,2133 & Valid \\
\hline 7 & 0,277 & 0,2133 & Valid \\
\hline \multicolumn{4}{|l}{} \\
\hline 8 & 0,388 & 0,2133 & Valid \\
\hline 9 & 0,444 & 0,2133 & Valid \\
\hline 10 & 0,489 & 0,2133 & Valid \\
\hline
\end{tabular}

Berdasarkan Tabel. 4 dapat diketahui bahwa pada seluruh item pertanyaan yang digunakan pada kuesioner nilai-nilai sosial diperoleh hasil bahwa nilai r-hitung yang didapatkan lebih besar dari r-tabel. Dengan demikian dapat dinyatakan bahwa item soal 1,2.3,4,5,6,7,8,9 dan 10 pada uji validitas variabel nilai-nilai sosial (X4) layak (valid) dijadikan alat ukur dalam penelitian.

\section{Validitas Variabel Minat Menjadi Akuntan Publik (Y)}

Adapun nilai r-tabel pada taraf signifikansi $\alpha$ 5\% $(0,05)$ adalah sebesar 0,2133 dan hasil dari pengujian validitas variabel $(\mathrm{Y})$ adalah sebagai berikut:

Tabel 5. Hasil Uji Validitas Variabel Y

\begin{tabular}{|c|c|c|c|}
\hline No. Item & R-hitung & R-tabel & Interpretasi \\
\hline 1 & 0,419 & 0,2133 & Valid \\
\hline 2 & 0,359 & 0,2133 & Valid \\
\hline 3 & 0,214 & 0,2133 & Valid \\
\hline 4 & 0,529 & 0,2133 & Valid \\
\hline 5 & 0,545 & 0,2133 & Valid \\
\hline 6 & 0,195 & 0,2133 & Tidak Valid \\
\hline 7 & 0,634 & 0,2133 & Valid \\
\hline 8 & 0,404 & 0,2133 & Valid \\
\hline 9 & 0,306 & 0,2133 & Valid \\
\hline 10 & 0,549 & 0,2133 & Valid \\
\hline
\end{tabular}

Sumber: Hasil Pengolahan Data dengan SPSS Versi 20

Berdasarkan Tabel. 5 dapat diketahui bahwa pada seluruh item pertanyaan yang digunakan pada kuesioner minat menjadi akuntan publik diperoleh hasil bahwa nilai r-hitung yang didapatkan 
lebih besar dari r-tabel. Dengan demikian dapatdinyatakan bahwa item soal 1,2.3,4,5,7,8,9 dan 10 pada uji validitas variabel Minat menjadi Akuntan Publik (Y) layak (valid) dijadikan alat ukur dalam penelitian.

\section{Uji Reliabilitas}

Adapun hasil uji reliabilitas adalah sebagai berikut:

Tabel 6. Hasil Uji Reliabilitas

\begin{tabular}{|l|c|c|c|}
\hline \multicolumn{1}{|c|}{ Variabel } & $\begin{array}{c}\text { Cronbach's } \\
\text { Alpha if item } \\
\text { Delete }\end{array}$ & $\begin{array}{c}\text { Cronbach's } \\
\text { Alpha }\end{array}$ & Interpretasi \\
\hline Prospek Karier (X1) & 0,748 & 0,6 & Reliabel \\
\hline Pengakuan Profesional (X2) & 0,818 & 0,6 & Reliabel \\
\hline Pertimbangan Pasar (X3) & 0,725 & 0,6 & Reliabel \\
\hline Nilai-Nilai Sosial (X4) Karier Sebagai & 0,773 & 0,6 & Reliabel \\
\hline Pemilihan & & 0,749 & Reliabel \\
\hline Akuntan Publik (Y) & & & \\
\hline
\end{tabular}

Sumber: Hasil Pengolahan Data dengan SPSS Versi 20

Hasil uji reliabilitas pada Tabel. 6 menunjukkan semua variabel yang dijadikan instrumen dalam penelitian ini, baik itu variabel prospek karier, pengakuan profesional, pertimbangan pasar, nilai-nilai sosial dan pemilihan karier sebagai akuntan publik adalah reliabel atau handal karena menunjukkan tingkat reliabilitas yang tinggi. Hal tersebut dibuktikan nilai koefisien alpha lebih dari 0,60 sehingga dapat digunakan sebagai alat ukur yang dapat diandalkan atau dipercaya.

\section{Uji Asumsi Klasik}

\section{Uji Normalitas}

Pengujian ini dilakukan pada data variabel yang diperoleh dengan angket skala likert. Pengujian normalitas dilakukan dengan uji kolmogorov-smimov. Suatu data dikatakan baik jika berdistribusi normal dan dikatakan berdistribusi normal apabila tingkat signifikansinya lebih besar dari 0,05 .

Tabel 7. One-Sample Kolmogorov-Smirnov Test

\begin{tabular}{|c|c|c|c|c|c|c|}
\hline & & $\begin{array}{c}\text { Pemilihan } \\
\text { Karir } \\
\text { Akuntan } \\
\text { Publik }\end{array}$ & $\begin{array}{c}\text { Prospek } \\
\text { Karir }\end{array}$ & $\begin{array}{l}\text { Pengakuan } \\
\text { Profesional }\end{array}$ & $\begin{array}{c}\text { Pertimbangan } \\
\text { Pasar }\end{array}$ & $\begin{array}{c}\text { Nilai-Nilai } \\
\text { Sosial }\end{array}$ \\
\hline $\mathrm{N}$ & & 85 & 85 & 85 & 85 & 85 \\
\hline Normal & Mean & 37,0235 & 35,4824 & 39,6941 & 32,6824 & 40,2000 \\
\hline Parameters $^{\mathrm{a}, \mathrm{b}}$ & Std. & 3,62851 & 3,32599 & 4,14621 & 3,07142 & 3,85079 \\
\hline & Deviation & & & & & \\
\hline Most & Absolute &, 112 &, 124 &, 118 & , 106 & ,085 \\
\hline Extreme & Positive &, 070 &, 124 &, 113 & , 106 & ,085 \\
\hline
\end{tabular}

a. Test distribution is Normal.

b. Calculated from data. 
Berdasarkan Tabel.7 hasil uji normalitas variabel prospek karier, pengakuan profesional, pertimbangan pasar, nilai-nilai sosial dan pemilihan karier menjadi akuntan publik menunjukkan nilai signifikansi lebih besar dari 0,05 dilihat dari kolom Asymp. Sig. (2 -tailed), sehingga dapat dikatakan bahwa data yang diuji berdistribusi normal.

2. Uji Linieritas

- Uji Linieritas bertujuan untuk mengetahui apakah dua variabel mempunyai hubungan yang linier atau tidak secara signifikan. Uji ini biasanya digunakan sebagai persyaratan dalam analisis

- korelasi dan analisis regresi linier.

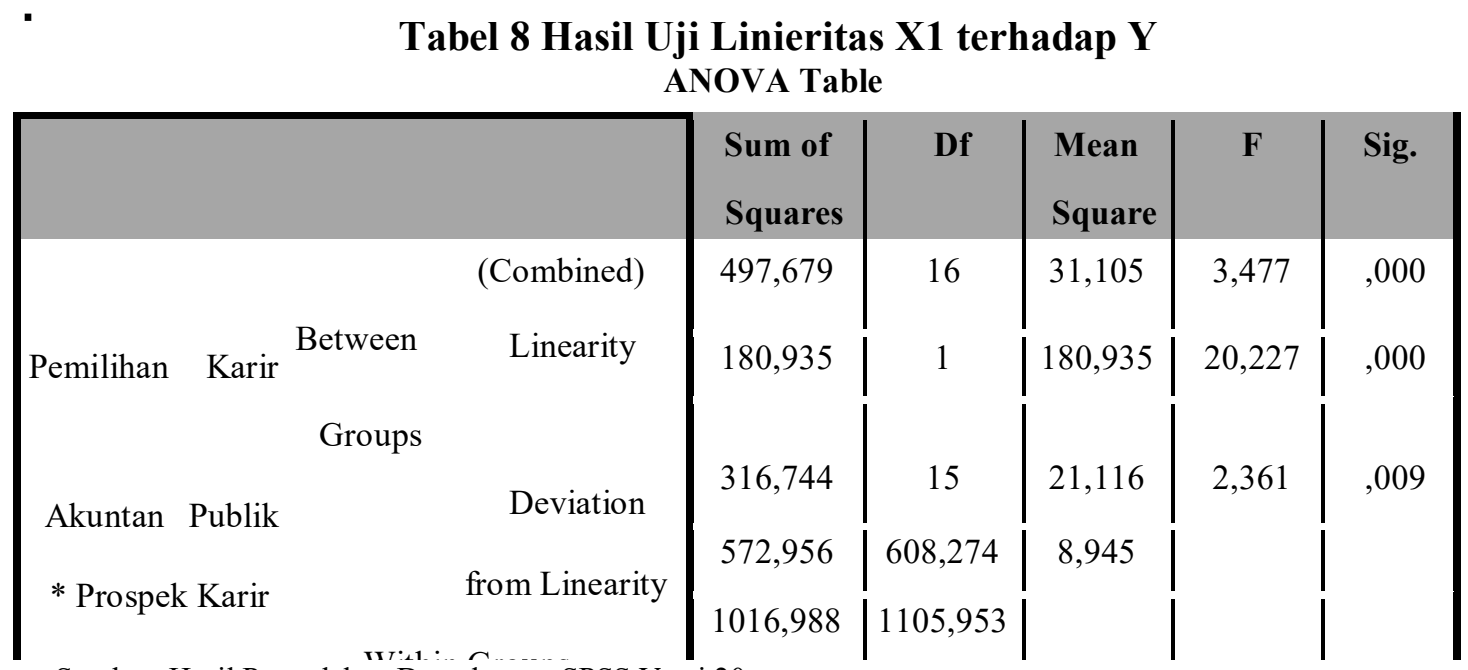

Sumber: Hasil Pengolahan Data dengan SPSS Versi 20

Dari hasil output Tabel. 8 diatas, diperoleh nilai signifikansi $=0,009$ lebih kecil dari 0,05 , yang artinya tidak terdapat hubungan yang linier secara signifikan antara variabel Prosepek Karier (X1) dengan Pemilihan Karier Akuntan Publik (Y).

Tabel .9 Hasil Uji Linieritas X2 terhadap Y ANOVA Table

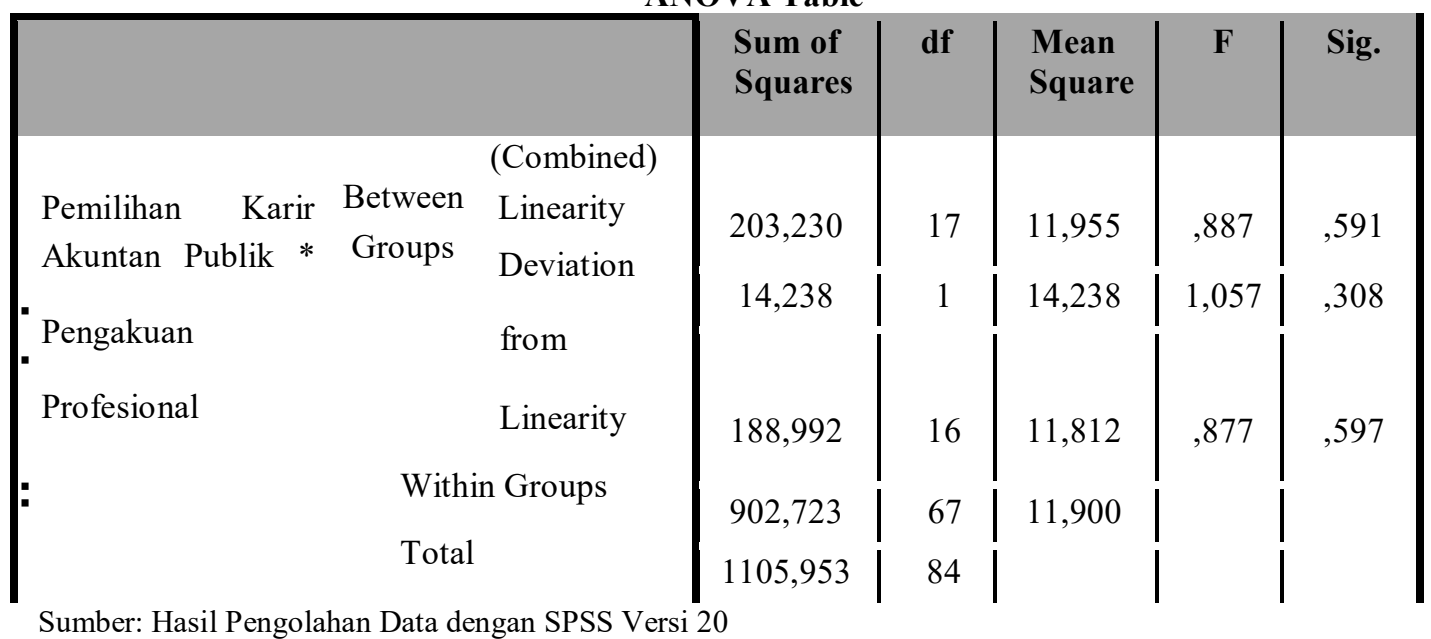

Dari hasil output Tabel. 9 diatas, diperoleh nilai signifikansi $=0,597$ lebih besar dari 0,05, yang artinya terdapat hubungan yang linier secara signifikan antara variabel Pengakuan Profesional (X2) dengan Pemilihan Karier Akuntan Publik (Y). 


\section{Tabel. 10 Hasil Uji Linieritas X3 terhadap Y ANOVA Table}

\begin{tabular}{|c|c|c|c|c|c|c|c|}
\hline & & & $\begin{array}{l}\text { Sum of } \\
\text { Squares }\end{array}$ & df & $\begin{array}{c}\begin{array}{c}\text { Me } \\
\text { an }\end{array} \\
\text { Square }\end{array}$ & $\mathbf{F}$ & Sig. \\
\hline & & (Combined) & 256,407 & 15 & 17,094 & 1,388 &, 178 \\
\hline Pemilihan & Between & Linearity & 43,020 & 1 & 43,020 & 3,494 &, 066 \\
\hline Akuntan Publik & Groups & Deviation & & & & & \\
\hline * Pertimbangan & & from & 213,387 & 14 & 15,242 & 1,238 & ,269 \\
\hline Pasar & & Linearity & & & & & \\
\hline & With & n Groups & 849,546 & 69 & 12,312 & & \\
\hline & Tota & & 1105,953 & 84 & & & \\
\hline
\end{tabular}

Sumber: Hasil Pengolahan Data dengan SPSS Versi 20

Dari hasil output Tabel. 10 diatas, diperoleh nilai signifikansi $=0,269$ lebih besar dari 0,05, yang artinya terdapat hubungan yang linier secara signifikan antara variabel Pertimbangan Pasar Kerja (X3) dengan Pemilihan Karier Akuntan Publik (Y)

\section{Tabel .11 Hasil Uji Linieritas X4 terhadap Y} ANOVA Table

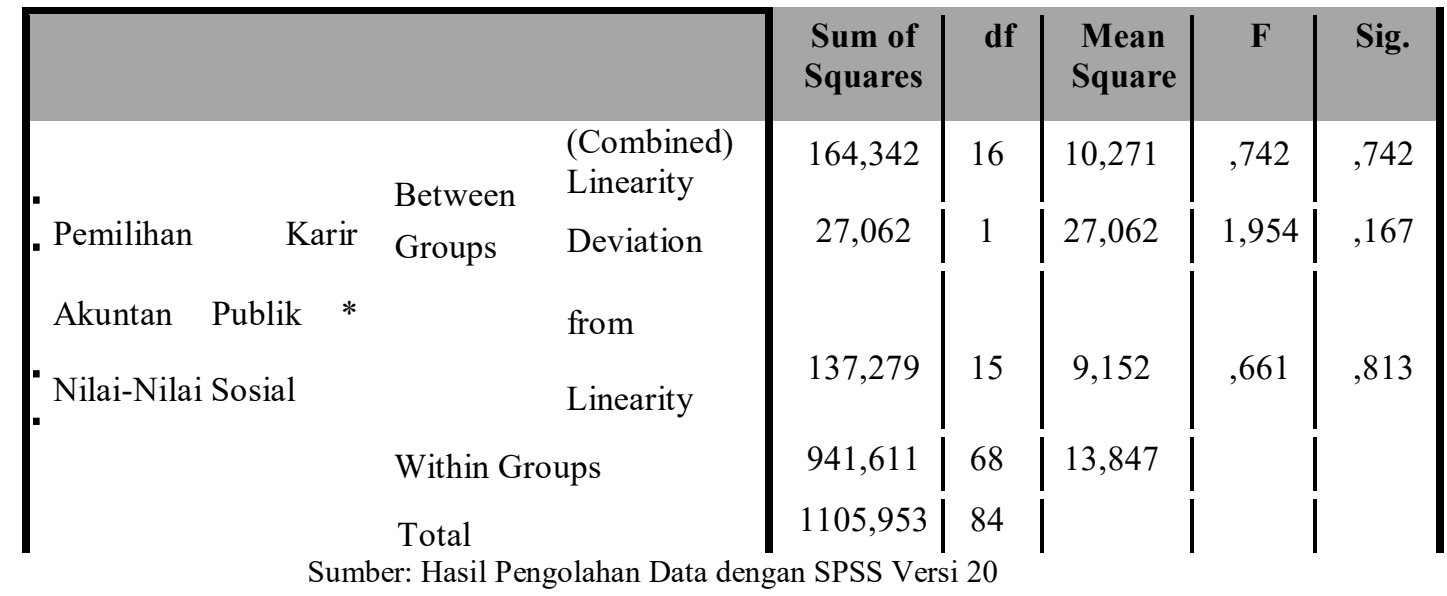

Dari hasil output Tabel. 11 diatas, diperoleh nilai signifikansi $=0,813$ lebih besar dari 0,05 , yang artinya terdapat hubungan yang linier secara signifikan antara variabel Nilai-Nilai Sosial (X4) dengan Pemilihan Karier Akuntan Publik (Y). 


\section{Pengujian Hipotesis}

a. Uji Parsial (Uji T)

Uji parsial digunakan untuk mengetahui apakah variabel independen (X) secara individu berpengaruh signifikan terhadap variabel dependen (Y). Pada uji t, jika nilai signifikan lebih kecil dari 0,05 atau 5\% maka hipotesis yang diajukan diterima atau dikatakan signifikan. Sedangkan jika nilai signifikan lebih besar dari 0,05 atau 5\% maka hipotesis yang diajukan ditolak atau dikatakan tidak signifikan.Hasil uji t pada penelitian ini dapat dilihat pada Tabel.12.

\section{Tabel 12. Hasil Uji T}

Coefficients $^{\mathrm{a}}$

\begin{tabular}{|c|c|c|c|c|c|}
\hline \multirow[t]{2}{*}{ Model } & \multicolumn{2}{|c|}{$\begin{array}{c}\text { Unstandardized } \\
\text { Coefficients }\end{array}$} & $\begin{array}{c}\text { Standardized } \\
\text { Coefficients }\end{array}$ & $\mathbf{T}$ & Sig. \\
\hline & B & $\begin{array}{c}\text { Std. } \\
\text { Error }\end{array}$ & Beta & & \\
\hline $\begin{array}{ll}\text { - Constant }) \\
\text { Prospek Karir }\end{array}$ & 9,031 & 6,969 & & 1,296 & ,199 \\
\hline Donglon &, 451 &, 104 & ,414 & 4,323 &, 000 \\
\hline 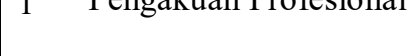 &,- 176 & 087 &,- 201 & $-2,031$ &, 046 \\
\hline Pertimbangan Pasar & ,260 &, 114 & ,220 & 2,272 &, 026 \\
\hline Nilai-Nilai Sosial &, 261 &, 094 &, 277 & 2,766 &, 007 \\
\hline
\end{tabular}

a. Dependent Variable: Pemilihan Karir Akuntan Publik

\section{b. Uji F (Simultan)}

Uji $\mathrm{F}$ digunakan untuk mengetahui pengaruh variabel bebas terhadap variabel terikat secara keseluruhan. Uji F dilakukan berdasarkan nilai probabilitas. Jika nilai signifikan lebih kecil dari 0,05 maka Ho ditolak, artinya ada pengaruh yang signifikan dari variabel independen terhadap variabel dependen. Sedangkan jika nilai signifikan lebih besar dari 0,05 maka Ho diterima, artinya tidak ada pengaruh yang signifikan dari variabel independen terhadap variabel dependen. Hasil uji F pada penelitian ini dapat dilihat di Tabel.13 berikut ini.

Tabel 13. Hasil Uji F

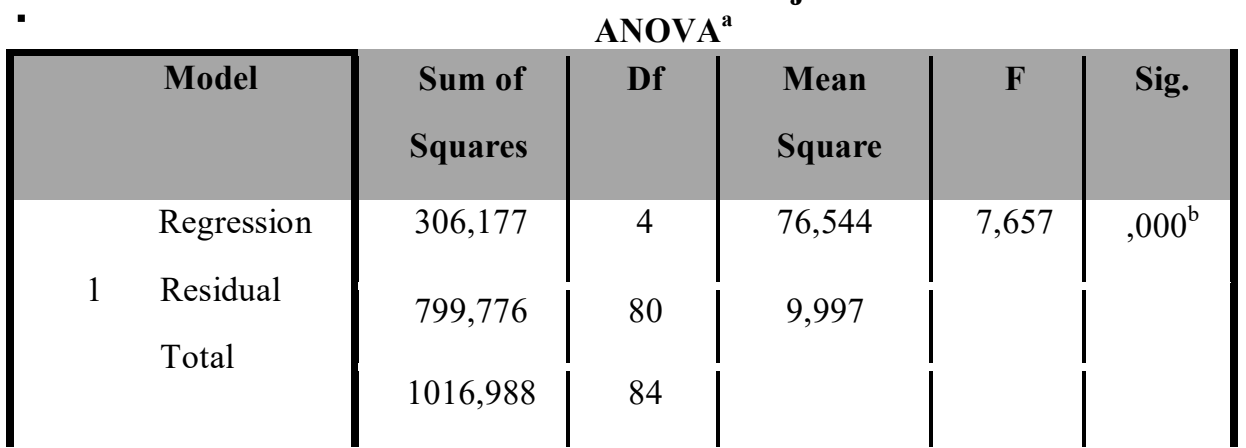

a. Dependent Variable: Pemilihan Karir Akuntan Publik

b. Predictors: (Constant), Nilai-Nilai Sosial, Prospek Karir, Pertimbangan Pasar, Pengakuan Profesional 


\section{c. Uji Determinasi (R2)}

Uji determinasi diperlukan untuk mengukur prospek karier (X1), Pengakuan Profesional (X2), Pertimbangan Pasar (X3) dan Nilai-Nilai Sosial (X4)berpengaruh terhadap minat pemilihan karier menjadi akuntan publik (Y)

Tabel 14. Hasil Uji R

Model Summary

\begin{tabular}{|c|c|c|c|c|}
\hline $\begin{array}{r}\text { M } \\
\text { odel }\end{array}$ & $\mathbf{R}$ & $\begin{array}{c}\mathbf{R} \\
\text { Square }\end{array}$ & $\begin{array}{l}\text { Adjusted } \\
\text { R Square }\end{array}$ & $\begin{array}{l}\text { Std. Error } \\
\text { of the }\end{array}$ \\
\hline 1 &, $526^{\mathrm{a}}$ & 277 & 241 & 3,16183 \\
\hline
\end{tabular}

a. Predictors: (Constant), Nilai-Nilai Sosial, Prospek Karir, Pertimbangan Pasar, Pengakuan Profesional

Berdasarkan Tabel.14 dan hasil perhitungan dengan spss versi 20. Dapat diketahui bahwa nilai $R$ square yang diperoleh sebesar 0,241 atau $24,1 \%$ angka tersebut memberikan arti bahwa prospek karier (X1), Pengakuan Profesional (X2), Pertimbangan Pasar (X3) dan Nilai-Nilai Sosial (X4) sebesar 24,1\% dan sisanya 75,9\% dipengaruhi oleh faktor lain diluar pembahasan ini.

Tabel 15. Ringkasan Pengujian Hipotesis

\begin{tabular}{|c|c|c|c|}
\hline No & Hipotesis & $\begin{array}{c}\text { Hasil Pengujian } \\
\text { Hipotesis }\end{array}$ & Keterangan \\
\hline 1. & $\begin{array}{l}\text { Prospek Karier berpengaruh positif } \\
\text { terhadap minat pemilihan karier } \\
\text { mahasiswa. }\end{array}$ & $\begin{array}{c}\text { Signifikansi } 0,000<0,05 \\
t_{\text {hitung }}>t_{\text {tabel }}(4,323>1,6641)\end{array}$ & $\begin{array}{c}\text { Hipotesis } 1 \\
\text { diterima }\end{array}$ \\
\hline 2. & 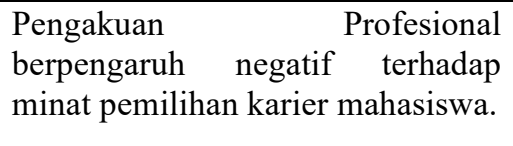 & $\begin{array}{c}\text { Signifikansi } 0,046<0,05 \\
\text { thitung }<\mathrm{t}_{\text {tabel }}(-2,031<1,6641)\end{array}$ & Hipotesis 2 ditolak \\
\hline 3. & $\begin{array}{l}\text { Pertimbangan Pasar berpengaruh } \\
\text { positif terhadap minat pemilihan } \\
\text { karier mahasiswa. }\end{array}$ & $\begin{array}{c}\text { Signifikansi } 0,026<0,05 \\
t_{\text {hitung }}>t_{\text {tabel }}(2,272>1,6641)\end{array}$ & $\begin{array}{c}\text { Hipotesis } 3 \\
\text { diterima }\end{array}$ \\
\hline 4. & $\begin{array}{l}\text { Nilai-Nilai Sosial berpengaruh } \\
\text { positif terhadap minat pemilihan } \\
\text { karier mahasiswa. }\end{array}$ & $\begin{array}{c}\text { Signifikansi } 0,007<0,05 \\
t_{\text {hitung }}>t_{\text {tabel }}(2,776>1,6641)\end{array}$ & $\begin{array}{l}\text { Hipotesis } 4 \\
\text { Diterima }\end{array}$ \\
\hline 5. & $\begin{array}{l}\text { Prospek Karier, Pengakuan } \\
\text { Profesional, Pertimbangan Pasar, } \\
\text { Nilai-Nilai Sosial secara bersama- } \\
\text { sama berpengaruh positif terhadap } \\
\text { minat pemilihan karier mahasiswa. }\end{array}$ & $\begin{array}{r}\text { Signifikansi } 0,000<0,05 \\
t_{\text {hitung }}>t_{\text {tabel }}(7,657>2,485)\end{array}$ & $\begin{array}{l}\text { Hipotesis } 5 \\
\text { Diterima }\end{array}$ \\
\hline
\end{tabular}

\section{Pembahasan}

\section{Prospek karir terhadap Minat Pemilihan Karier sebagai Akuntan Publik}

Hasil penelitian ini meunjukkan bahwa prospek karier berpengaruh positif terhadap minat Pemilihan Karier sebagai Akuntan Publik. Prospek karir merupakan pandangan terhadap pengembangan dari sebuah profesi pekerjaan. Informasi tentang prospek karir dapat diakses dari berbagai sumber seperti dari buku, media elektronik dan pengamatan langsung terhadap karir tersebut. Berdasarkan pengujian secara parsial yang dilakukan diketahui bahwa mahasiswa yang memandang prospek karier dari sebuah profesi atau pekerjaan yang tinggi maka akan semakin 
berminat memilih karier sebagai akuntan publik. Hal tersebut disebabkan karena miliki karier sebagai akuntan publik dirasa oleh para mahasiswa kedepannya akan mempunyai prospek yang cukup menjanjikan. Hasil penelitian ini sesuai dengan penelitian yang telah dilakukan oleh Risqullah (2018) yang menyatakan bahwa Prospek karir berpengaruh positif dan signifikan terhadap minat berkarier mahasiswa akuntansi sebagai Certified Public Accountants of Indonesia.

2. Pengakuan Profesional terhadap Minat Pemilihan Karier sebagai Akuntan Publik Hasil penelitian ini menunjukkan bahwa pengakuan profesional berpengaruh negative terhadap minat Pemilihan Karier sebagai Akuntan Publik. Pengakuanprofesional merupakan suatu penghargaan yang berwujud non-finansial yang berhubungan dengan pengakuan terhadap prestasi. Dengan diakuinya prestasi kerja akan dapat meningkatkan kualitas pekerjaan yang dihasilkan dan dapat meningkatkan motivasi dalam pencapaian karir yang lebih baik. Dengan demikian semakin mahasiswa mengetahui tentang pengakuan profesional dari sebuah pekerjaan maka minat minat Pemilihan Karier sebagai Akuntan Publik akan semakin rendah. Hasil penelitian ini sesuai dengan penelitian yang telah dilakukan oleh Senoadi (2015) yang menyatakan bahwa pengakuan profesional minat berkarier mahasiswa akuntansi sebagai Certified Public Accountants of Indonesia.

3. Pertimbangan Pasar Kerja terhadap Minat Pemilihan Karier sebagai Akuntan Publik Hasil penelitian ini menunjukkan bahwa pertimbangan pasar berpengaruh positif terhadap minat Pemilihan Karier sebagai Akuntan Publik. Pertimbangan pasar kerja merupakan sarana yang mengkoordinasikan pertemuan antara pencari kerja dan perusahaan yang memerlukan tenaga kerja. Pasar kerja merupakan sarana tempat pertemuan antara penjual dan pembeli tenaga kerja. Dengan demikian semakin mahasiswa mengetahui tentang pengakuan profesional dari sebuah pekerjaan maka minat pertimbangan pasar sebagai Akuntan Publik akan semakin tinggi pula. Hasil penelitian ini sesuai dengan penelitian yang telah dilakukan oleh Senoadi (2015) yang menyatakan bahwa pertimbangan pasar berpengaruh positif terhadap minat berkarier mahasiswa akuntansi sebagai Certified Public Accountants of Indonesia.

\section{Nilai-nilai Sosial terhadap Minat Pemilihan Karier sebagai Akuntan Publik}

Hasil penelitian ini meunjukkan bahwa nilai-nilai sosial berpengaruh positif terhadap minat Pemilihan Karier sebagai Akuntan Publik. Nilai-nilai sosial berkaitan dengan pandangan masyarakat terhadap nilai-nilai sosial dari suatu karir yang dipilih. Sehingga semakin mahasiswa paham dan mengetahui tentang nilai-nilai sosial dari profesi akuntan publik maka minat pemilihan berkarier sebagai akuntan publik akan semakin tinggi juga. Hasil penelitian ini sesuai dengan penelitian yang telah dilakukan oleh Aprilyian (2011) yang menyatakan bahwa nilai sosial berpengatuh positif terhadap minat berkarier mahasiswa akuntansi sebagai Certified Public Accountants of Indonesia.

\section{KESIMPULAN DAN SARAN}

Berdasarkan hasil penelitian yang dilakukan dapat disimpulkan secara parsial bahwa prospek karier, pertimbangan pasar kerja, nilai-nilai sosial dan prospek karier mempunyai pengaruh yang positif terhadap pemilihan karir sebagai akuntan publik. Artinya faktor Prospek karier dapat mempengaruhi minat mahasiswa akuntansi di Universitas Muhammadiyah Metro dalam pemilihan karier sebagai akuntan publik. Sedangkan pengakuan profesional mempunyai pengaruh yang negatif terhadap pemilihan karir sebagai akuntan publik. Dan secara simultan dapat disimpulkan bahwa prospek karier, pengakuan profesional, pertimbangan pasar kerja dan nilai-nilai sosial bersamasama berpengaruh terhadap minat mahasiswa akuntansi di Universitas Muhammadiyah Metro dalam pemilihan karier sebagai akuntan publik. Adapun saran yang dapat diberikan setelah penelitian ini ialah: memberikan kuesioner secara online bukan secara langsung dengan menggunakan google doc agar penelitian dapat dilakukan secara cepat dan efisien dan mengkategorikan responden 
lebih luas, tidak hanya mencakup Fakultas Ekonomi dan Bisnis Universitas Muhammadiyah Metro, namun bisa pada beberapa universitas, serta dengan jumlah responden yang lebih besar.

\section{DAFTAR PUSTAKA}

Ajzen. 1986. Perilaku Organisasi, Konsep, Kontroversi dan Aplikasi. Edisi Kedelapan Bahasa Indonesia

Aprilyan, Lara Absara dan Herry Laksito. 2011. "Faktor-faktor yang Mempengaruhi Mahasiswa Akuntansi dalam Pemilihan Karir Menjadi Akuntan Publik (Studi Empiris pada Mahasiswa Akuntansi UNDIP dan Mahasiswa Akuntansi UNIKA). Jurnal Fakultas Ekonomi Universitas Diponegoro. Semarang

Bere Laka, Jesi Kristin P. Sugiarti. Yunus Harjito. 2019. Analisis Faktor-Faktor Yang Mempengaruhi Mahasiswa Dalam Pemilihan Karir Sebagai Akuntan Publik (Studi Empiris Pada Perguruan Tinggi Swasta Di Surakarta) Vol 2. No. 2. Journal of Islamic Finance Accounting. Universitas Setia Budi Surakarta.

Ghozali, Imam. 2018. Aplikasi Analisis Multivariate Dengan Program SPSS. Semarang: Badan Penerbit Universitas Diponegoro.

Merdekawati, Dian Putri dan Sulistyawati, Ardiani Ika. 2011. Faktor-faktor yang Mempengaruhi Pemilihan Karir Akuntan Publik dan Non Akuntan Publik. Aset. 13 (1): 9-19

Rizqullah, Naufal And Prabowo, Tri Jatmiko Wahyu. 2018. Faktor-Faktor Yang Mempengaruhi Persepsi Mahasiswa Akuntansi Terhadap Minat Pemilihan Karier Sebagai Certified Public Accountants Of Indonesia (Studi Empiris pada Mahasiswa Akuntansi Universitas Diponegoro). Undergraduate thesis, Fakultas Ekonomika dan Bisnis Universitas Diponegoro Semarang.

Senjari Richa, Amir Hasan. Azhari Sofyan. 2016. Pengaruh Motivasi, Lingkungan Kerja Dan Nilai Sosial Terhadap Minat Mahasiswa Akuntansi Dalam Memilih Karir Sebagai Akuntan Publik. Artikel Jurnal Online Mahasiswa Fakultas Ekonomi Universitas Riau.

Senoadi, Yohanes Prabowo. 2015. Faktor-Faktor Yang Mempengaruhi Pemilihan Karir Lulusan Sarjana Menjadi Akuntan Publik. Media Riset Akuntansi, Auditing \& Informasi Vol. 15 No. 2 September 2015. Universitas Trisakti. Jakarta.

Sugiyono. 2016. Aplikasi Analisis Multivariate Dengan Program SPSS. Universitas Diponegoro Semarang

Surat Keputusan Menteri Keuangan No.43 Tahun 1997 tentang Jasa Akuntan menggantikan Keputusan Menteri Keuangan No. 763 Tahun 1986.

Suyono, Nanang Agus. 2014. Analisis Faktor-Faktor Yang Mempengaruhi Pemilihan Karir Sebagai Akuntan Publik (Studi Empiris Pada Mahasiswa Akuntansi Unsiq). Jurnal Penelitian dan Pengabdian kepada Masyarakat Universitas Sains Al-Qur'an (UNSIQ) Volume 1 No. 2 Program Studi Akuntansi Universitas Sains Al-Qur'an (UNSIQ) Wonosobo

Undang-Undang Republik Indonesia Nomor. 5 Tahun 2011 tentang Akuntan Publik dan Menteri Keuangan Nomor 17/PMK.01.2008 tentang Jasa Akuntan Publik.

Widyanti Rina, Dedi Saputra. 2018. Pengaruh Penghargaan Finansial, Pertimbangan Pasar Kerja Dan Lingkungan Keluarga Terhadap Minat Menjadi Akuntan Publik (Studi Empiris Mahasiswa S1 Akuntansi Universitas Ekasakti) Jurnal Menara Ekonomi: Penelitian dan Kajian Ilmiah Bidang Ekonomi. Volume 4 No. 2 Fakultas Ekonomi Universitas Muhammadiyah Sumatera Barat.

http://jtanzilco.com/blog/detail/1 150/slug/profesi-akuntan-publik-di-tahun-2019-tantangan- dan-harapan. 2018. Profesi Akuntan Publik di Tahun 2019 (Tantangan dan Harapan) Dendy Octavian Patama, S.E. 2018. 